\title{
PHYTOCHEMICAL SCREENING AND RENAL EFFECTS OF ETHANOLIC EXTRACT OF ERIOBOTRYA JAPONICA FRUITS AND SEEDS IN ALLOXAN INDUCED DIABETIC RATS
}

\author{
SABEEHA SHAFI ${ }^{*}$, NAHIDA TABASSUM \\ Department of Pharmaceutical Sciences, University of Kashmir, Hazratbal, Srinagar, Kashmir, Jammu and Kashmir (India) \\ Email: sabeeha_shafi@yahoo.com
}

Received: 22 May 2017, Revised and Accepted: 22 Jul 2017

\begin{abstract}
Objective: The main aim of the present study was to evaluate the phytochemical constituents, and renal effects of the ethanolic extract of the fruits and seeds of Eriobotrya japonica, commonly called as Loquat in Kashmir. So far, no such study was carried in Kashmir.

Methods: Phytochemical screening involved the standard procedures. Diabetes was induced in albino rats using alloxan monohydrate $(120 \mathrm{mg} / \mathrm{kg}$ b. w) given i. p prepared in sterile saline. Rats were divided into 8 groups of 6 rats in each group. The ethanolic extract of Eriobotrya japonica fruits were given in doses of $50 \mathrm{mg} / \mathrm{kg}, 100 \mathrm{mg} / \mathrm{kg}$, and $200 \mathrm{mg} / \mathrm{kg} \mathrm{b}$. w. whereas the ethanolic extract of Eriobotrya japonica deeds were given in doses of 100 and $200 \mathrm{mg} / \mathrm{kg}$ b.w. The renal effects were determined by estimating the kidney function tests i.e., serum urea levels, serum creatinine levels and serum total proteins. The effects were compared with the normal control rats.
\end{abstract}

Results: Phytochemical screening revealed the presence of some useful phytoconstituents. alkaloids, glycosides and flavonoids in both extracts. The renal effects showed changes in alloxan-induced diabetic rats when treated with the ethanolic extract of the fruit and seeds of Eriobotrya japonica.

Conclusion: The ethanolic extract of E. J units and seeds have some useful Phytonstihut and there are some renal changes by the ethanolic extraction of E. B. F and S when admi to alloxaun inderced diabetic rats.

Keywords: Eriobotrya japonica fruits and seeds, Phytochemical screening, Renal effects

(C) 2018 The Authors. Published by Innovare Academic Sciences Pvt Ltd. This is an open access article under the CC BY license (http://creativecommons.org/licenses/by/4.0/] DOI: http://dx.doi.org/10.22159/ijcpr.2018v10i1.24399

\section{INTRODUCTION}

Diabetes is a dreadful disease that kills after every 10 seconds. The main cause being obesity, taking of fast foods and sedentary lifestyle. India is having the highest number of diabetics in the world. It is a multifactorial disease which is characterized by hyperglycemia, lipoprotein abnormalities, raised the basal metabolic rate, defect in reactive oxygen species scavenging enzymes and high oxidative stress-induced damage to pancreatic beta cells. Long-term complications, including retinopathy, nephropathy, neuropathy and angiopathy and several others are associated with it [1] Heart diseases are more common in people having diabetes [2] Many efforts are going on to minimize the complications related to diabetes. Great demand has been for herbal plant products due to low cost, easy availability and lesser side effects. India has been known to be a rich repository of medicinal plants [3]. There are about 2. 50.000 higher plants species are available on earth: out of which more than 80.000 are medicinal. While the Ayurveda system of medicine uses about 700 species, the emphasis of development of new biologically active molecule has been gradually replaced by use of total herbs as medicine and food supplements [4-10].

Eriobotrya japonica commonly called as Loquat in kashmir a number of pharmacological activities like anti-oxidant, antiviral, cytotoxic, hepatoprotective, anti-inflammatory/antitussive. Antidiabetic activity has been reported from the leaves of this plant. [11-16] Very less work has been done on the fruit and seeds of this plant. The present study was taken to evaluate the phytochemical constituents and renal effects of the fruits and seeds in alloxan-induced diabetic rats.

\section{MATERIALS AND METHODS}

\section{Plant material}

Eriobotrya japonica fruits (Family Rosaceae) were collected from Shalimar area of the Srinagar district, collected in the months of April to June. They were authenticated by a plant taxonomist, Dr Naqshi in the Centre of Plant Taxonomy, University of Kashmir, Srinagar. A sample of the fruits was deposited in the herbarium of the Department of Taxonomy, University of Kashmir under voucher specimen number 1012(KASH) for future reference. The fruits were kept in a ventilated room and air dried with outside temperature ranging between 18 to $32{ }^{\circ} \mathrm{C}$ pulverized into a coarse powder by a grinder. The seeds use they're separated from fruits. Both dried fruits and seeds were pulverized of fruits of $E$. J.

\section{Preparation of the extract}

Powdered material was allowed to macerate with $50 \%$ ethanol for $48 \mathrm{~h}$. After $48 \mathrm{~h}$, the ethanolic extract was filtered using Whatmans filter paper. Fresh ethanol was used for the second maceration. The filtrates obtained were combined and the solvent was recovered. After the solvent was recovered, the extract was then evaporated to dryness. The process repeated a number of times. The yield was noted. The final extract was refrigerated at $4{ }^{\circ} \mathrm{C}$ for future use in experimental studies. In the same way ethanolic extract of the Eriobotrya japonica seeds was also prepared.

\section{Drugs and chemicals}

Acacia gum, Acetic anhydride, Albumin Kit, Chloroform, Citric acid, Concentrated hydrochloric acid, Concentrated sulphuric acid, Diethyl ether, Ehanol, Ferric chloride, Formaldehyde, Glacial acetic acid, Glucose Kit, Sterile Saline, Magnesium, Methanol, Olive oil, Total Protein Kit, Tri-sodium citrate, Urea Enzymatic Kit, Wagners reagent, Zinc. These chemicals were obtained from Central Drug House Ltd New Delhi 110002, Qualigen fine chemicals, Crest Biosystems Goa India, Merck Laboratories, Accurex Biomedical Pvt Ltd, Bengal chemicals and Pharmaceutical Ltd, Sisco Research Laboratories, Mumbai. Rat feed was obtained from Ashirwad Industries Works, Tripari, Tehsil Kharar, Mohali, Punjab.

\section{Phytochemical screening [17-19]}

The extract obtained was subjected to qualitative tests for identification of different constituents like tannins, alkaloids, saponins, glycosides, terpenes, phenolics, flavonoids, carbohydrates, proteins and steroids, by using simple and standard qualitative methods. 


\section{Pharmacological study [20-24]}

\section{Animals and exposure conditions}

Albino rats weighing about 180-220 gm were taken for conducting the studies. The animals were procured from Central Animal House, IIIM (Indian Institute of Integrative Medicine) Jammu and were housed in clean polypropylene cages. Standard environmental conditions were kept standard such as a temperature ranging from 18 to $32{ }^{\circ} \mathrm{C}$, relative humidity (70\%) and $12 \mathrm{~h}$ dark/light cycle were maintained in the quarantine. All the animals were fed with rodent pellet diet (Ashirwad Industries) and water ad-libitum under strict hygienic conditions. All procedures were performed in accordance to CPCSEA guidelines after approval from the Institutional Animal and Ethics Committee (IAEC) of the Department of Pharmaceutical Sciences, University of Kashmir [No. F-IAEC (Pharm. Sc) APPROVAL.

\section{Induction of diabetes}

Diabetes was induced in albino rats using alloxan monohydrate. They were acclimatized for a period of $7 \mathrm{~d}$. After an overnight fasting, hyperglycaemia was induced by administration of single dose of alloxan monohydrate (AM) $(120 \mathrm{mg} / \mathrm{kg} \mathrm{b}$. w.) given i.p. prepared in sterile saline. After $5 \mathrm{~d}$ of alloxan treatment, blood glucose levels were checked. Rats having blood glucose levels (BGL) $>250 \mathrm{mg} / \mathrm{dl}$ were selected for the study. The animals were divided into 8 groups having 6 rats in each group. The ethanolic extract of Eriobotrya japonica fruits were given in doses of $50 \mathrm{mg} / \mathrm{kg}, 100 \mathrm{mg} / \mathrm{kg}$, and $200 \mathrm{mg} / \mathrm{kg}$ b.w. whereas the ethanolic extract of Eriobotrya japonica seeds were given in doses of 100 and $200 \mathrm{mg} / \mathrm{kg}$ b.w. The renal effects were determined by estimating the kidney function tests i.e., serum urea levels, serum creatinine levels and serum total proteins. The resole were compared with the normal control rats.

\section{Renal activity}

The ethanolic extract of Eriobotrya japonica fruits (EBJF) was administered orally once daily to albino rats at the dose levels of 50 $\mathrm{mg} / \mathrm{kg} \mathrm{b}$. w $100 \mathrm{mg} / \mathrm{kg} \mathrm{b}$. w and $200 \mathrm{mg} / \mathrm{kg} \mathrm{b}$. w respectively. The ethanolic extract of Eriobotrya japonica seeds (EBJS) was also administered orally once daily to albino rats at the dose levels of 100 $\mathrm{mg} / \mathrm{kg} \mathrm{b}$. w. and $200 \mathrm{mg} / \mathrm{kg} \mathrm{b}$. w. respectively and compared with mice of Normal Control group. To study renal activity, animals of either sex (180-220 gms b. w.) were divided into eight groups of six rats each. The treatment was given as per the following protocol.

Group I: Normal Control (2\% aqueous gum acacia)

Group II: Diabetic Control Group (Alloxan Monohydrate only) (AM)

Group III: AM+Standard Drug Group (Glibenclamide-10 mg/kg b.w.)

Group IV: AM+EBJF (50 mg/kg b.w.)

Group V: AM+EBJF (100 mg/kg b.w.)

Group VI: AM+EBJF (200 mg/kg b.w.)

Group VII: AM+EBJS (100 mg/kg b.w.)

\section{Group VIII: AM+EBJS (200 mg/kg b.w.)}

The treatment was continued for $10 \mathrm{~d}$. During this period, mice of Normal Control group received only 2\% gum acacia.

\section{Assessment of renal activity}

After $10 \mathrm{~d}$ of treatment, the rats fasted overnight and on the $11^{\text {th }} \mathrm{d}$ the rats were anaesthetized with diethyl ether and a blood sample from each animal was collected by cardiac puncture, in sterilized centrifuge tubes. The blood samples were allowed to coagulate at 30 ${ }^{\circ} \mathrm{C}$. Serum was separated by centrifugation at $2500 \mathrm{r} / \mathrm{min}$ at $30^{\circ} \mathrm{C}$ for $15 \mathrm{~min}$ and subjected to biochemical investigations using standard test kits.

\section{Determination of urea [26]}

Urease splits urea into ammonia and carbon dioxide. Ammonia released in this reaction reacts with hypochlorite and phenolic chromogen to produce a green colour. The absorbance of this green colour at $578 \mathrm{~nm}$. (570-620) is directly propotional to the concentration of urea in the specimen. The components of the assay mixture are Phosphate buffer; $\mathrm{pH}$ 7.0-35 mmol/l; Urease-15 $\mathrm{KU} / \mathrm{l}$; Phenolic Chromogen-2 mmol/l; Hypochlorite $4 \mathrm{mmol} / \mathrm{l}$ Activators and preservative. The sample volume taken was $0.01 \mathrm{ml}$ and the reagent volume was $2.0 \mathrm{ml}$. The standard concentration was $40 \mathrm{mg} \% .2 .0 \mathrm{ml}$ procedure was followed. Mixed and incubated the assay mixture at $37^{\circ} \mathrm{C}$ for $5 \mathrm{~min}$. After completion of incubation measured the absorbance of assay mixture against blank at $578 \mathrm{~nm}(570-620 \mathrm{~nm})$.

\section{Calculation}

$$
\text { Urea in mg \% }=\frac{\text { Absorbance of sample }}{\text { Absorbance of standard }} \times 40
$$

\section{Determination of creatinine [27]}

Creatinine in alkaline medium reacts with picrate to produce an orange colour. This colour absorbs light at $492 \mathrm{~nm}$. (490-510 nm). The rate of increase in absorbance is directly proportional to the concentration of creatinine in the specimen. The components of the working solution contain sodium picrate and sodium hydroxide. The sample volume was $0.05 \mathrm{ml}$ and the reagent volume was $1.0 \mathrm{ml}$. The standard concentration is $2 \mathrm{mg} \%$. The wavelength used was at $492 \mathrm{~nm}(490-510 \mathrm{~nm}) .1 .0 \mathrm{ml}$ procedure was followed. Recorded absorbance assay mixture at exactly 30 seconds after Standard/Specimen addition and then again at 90 seconds.

\section{Calculation}

Calculated the average change in absorbance per minute (Abs.) of standard and specimen.

Abs. $=$ Abs. at 90 sec.---Abs. at $30 \mathrm{sec}$.

Serum Creatinine (mg \%) = Abs. of Specimen x 2

Abs. of Standard

Table 1: Results of phytochemical screening

\begin{tabular}{lll}
\hline Phytochemical constituents & Results & Eriobotrya japonica seeds EBJS \\
\cline { 2 - 3 } & Eriobotrya japonica fruits EBJF & - \\
\hline Tannins & - & + \\
Alkaloids & + & - \\
Saponins & - & - \\
Glycosides & + & - \\
Terpenes & - & + \\
Phenolics & - & - \\
Flavonoids & + & - \\
Carbohydrates & - & - \\
Proteins & - & \\
Steroids & - &
\end{tabular}

The percentage yield of $\mathrm{EBJF}=30 \%$, EBJS $=11 \%$ 


\section{Determination of total proteins [28]}

Proteins, in an alkaline medium, bind with the cupric ions present in the biuret reagent to form a blue-violet coloured complex. The intensity of the colour formed is directly proportional to the number of proteins present in the sample. The solutions contain Biuret reagent and Protein standard $(8 \mathrm{mg} / \mathrm{dl})$. The volume of the sample was $0.02 \mathrm{ml}$ and that of standard protein was $0.02 \mathrm{ml}$. The wavelength of $550 \mathrm{~nm}$ was used. Mixed well and incubated at $37^{\circ} \mathrm{C}$ for 10 min. measured the absorbance of the Standard (Abs. S), and Test Sample (Abs. T) against the Blank within 60 Min.

\section{Calculation}

$$
\text { Total proteins in } \mathrm{g} / \mathrm{dl}=\frac{\text { Abs. } \mathrm{T}}{\mathrm{Abs} . \mathrm{S}} \times 8
$$

\section{Statistical analysis}

All the results were expressed as mean \pm SEM. One way analysis of variance (ANOVA) was used for the statistical analysis of data. Students " $\mathrm{t}$ " test was used for determining the significance. A probability value of $p>0.05$ was considered as non-significant, ${ }^{*} \mathrm{p}<0.05$-significant, ${ }^{* *} \mathrm{p}<0.01$-highly significant and ${ }^{* * *} \mathrm{p}<0.001$ as very highly significant.

\section{RESULTS}

\section{Phytochemical screening (table 1)}

The phytochemical investigation of ethanolic extract of Eriobotrya japonica fruits and seeds was carried out by standard procedures.

Table 2: Results of renal activity

\begin{tabular}{llllr}
\hline Group & Treatment & $\begin{array}{l}\text { Serum glucose levels } \\
\mathbf{m g} / \mathbf{d l}\end{array}$ & $\begin{array}{l}\text { Serum urea levels } \\
\text { (mg/dl) }\end{array}$ & $\begin{array}{l}\text { Serum creatinine } \\
\text { levels (mg/dl) }\end{array}$ \\
\hline I & Normal Control & 84.71 & $22.32 \pm 3.75$ & $\begin{array}{l}\text { Serum total proteins } \\
\text { levels (g/dl) }\end{array}$ \\
II & Diabetic Rats & 271.02 & $23.06 \pm 0.69$ & $0.85 \pm 0.07$ \\
III & Standard drug glibenclamide & 114.84 & $20.82 \pm 1.32$ & $1.14 \pm 0.12$ \\
IV & EBJF 50 mg/kg & 157.84 & $26.46 \pm 3.84$ & $0.76 \pm 0.08$ \\
V & EBJF 100 mg/kg & 128.64 & $24.31 \pm 2.65$ & $1.19 \pm 0.87$ \\
VI & EBJF 200 mg/kg & 82.82 & $17.92 \pm 2.44$ & $1.06 \pm 0.64$ \\
VII & EBJS 100 mg/kg & 155.54 & $26.11 \pm 2.25$ & $0.89 \pm 0.65$ \\
VIII & EBJS 200 mg/kg & 120.74 & $29.06 \pm 2.01$ & $0.84 \pm 0.16$ \\
\hline
\end{tabular}

The observations are mean \pm SEM of 6 animals as compared to that of Normal Control group (One way ANOVA followed by students " $\mathrm{t}$ "test).

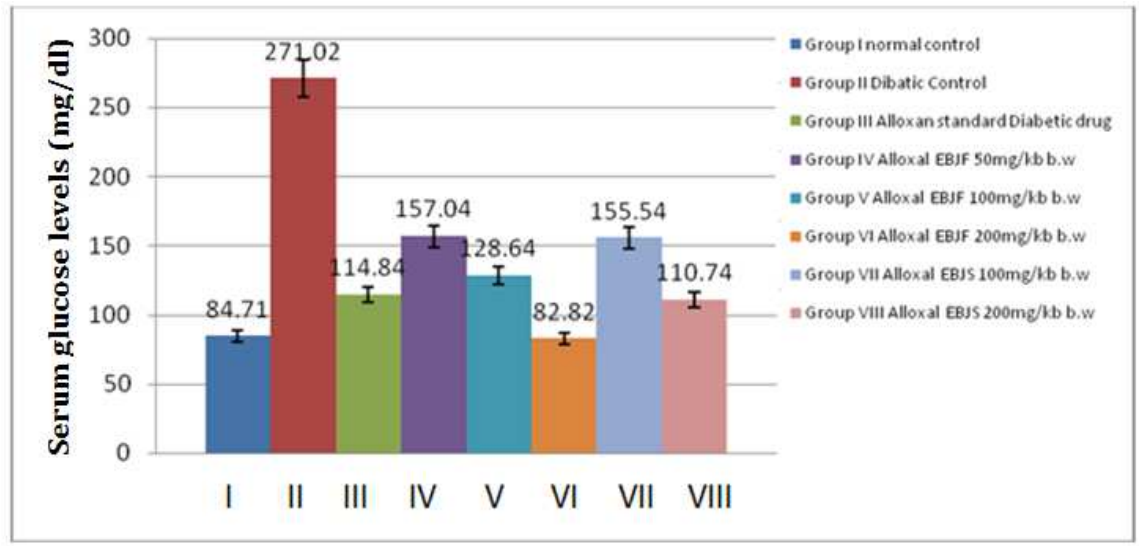

Fig. 1: Effect of Eriobotrya japonica fruits and seeds on serum glucose levels in alloxan-induced diabetic rats

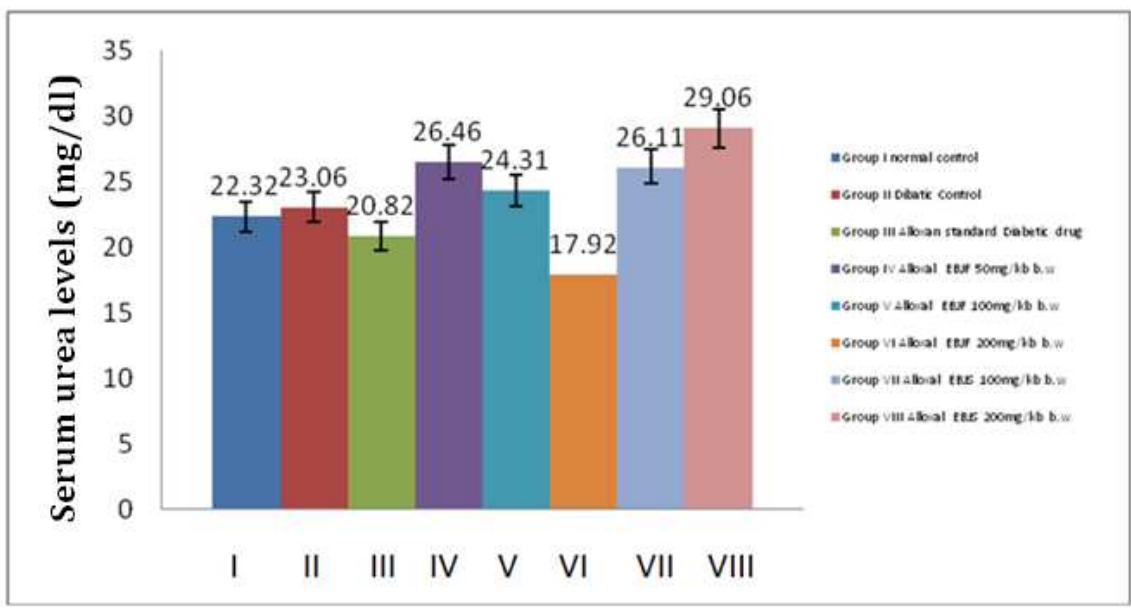

Fig. 2: Effect of Eriobotrya japonica fruits and seeds on serum urea levels in alloxan-induced diabetic rats 
Table 3: Results of body weight

\begin{tabular}{lll}
\hline Group & Treatment & Body Weight in gms \\
\hline I & Normal Control & $222.05 \pm 4.74$ \\
II & Diabetic Rats & $124.76 \pm 2.35$ \\
III & Standard drug glibenclamide & $137.50 \pm 3.00$ \\
IV & EBJF $50 \mathrm{mg} / \mathrm{kg}$ & $171.47 \pm 2.74$ \\
V & EBJF $100 \mathrm{mg} / \mathrm{kg}$ & $172.62 \pm 4.05$ \\
VI & EBJF $200 \mathrm{mg} / \mathrm{kg}$ & $176.41 \pm 3.52$ \\
VII & EBJS $100 \mathrm{mg} / \mathrm{kg}$ & $162.37 \pm 3.08$ \\
VIII & EBJS $200 \mathrm{mg} / \mathrm{kg}$ & $167.20 \pm 3.58$ \\
\hline
\end{tabular}

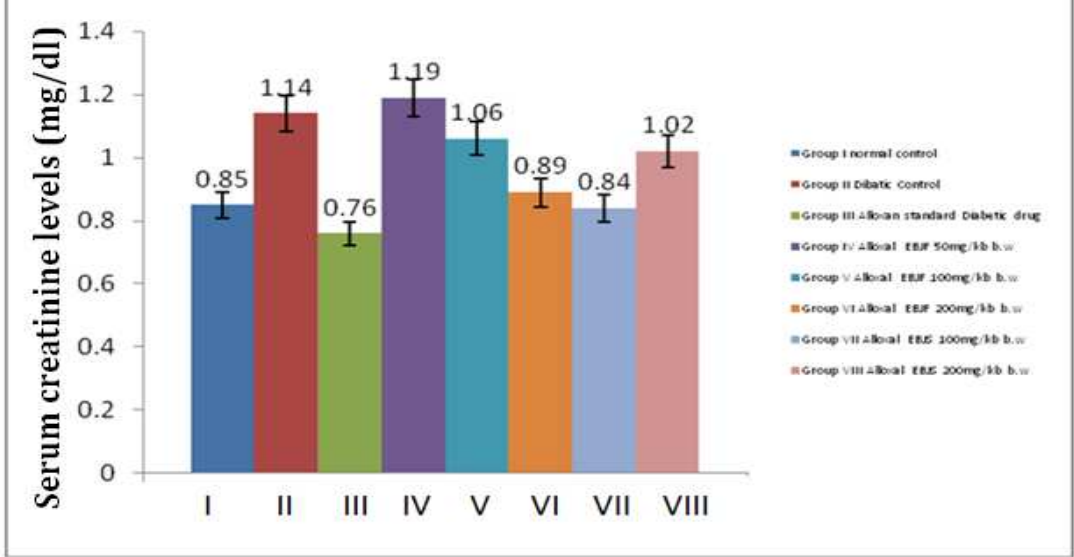

Fig. 3: Effect of Eriobotrya japonica fruits and seeds on serum creatinine levels in alloxan-induced diabetic rats

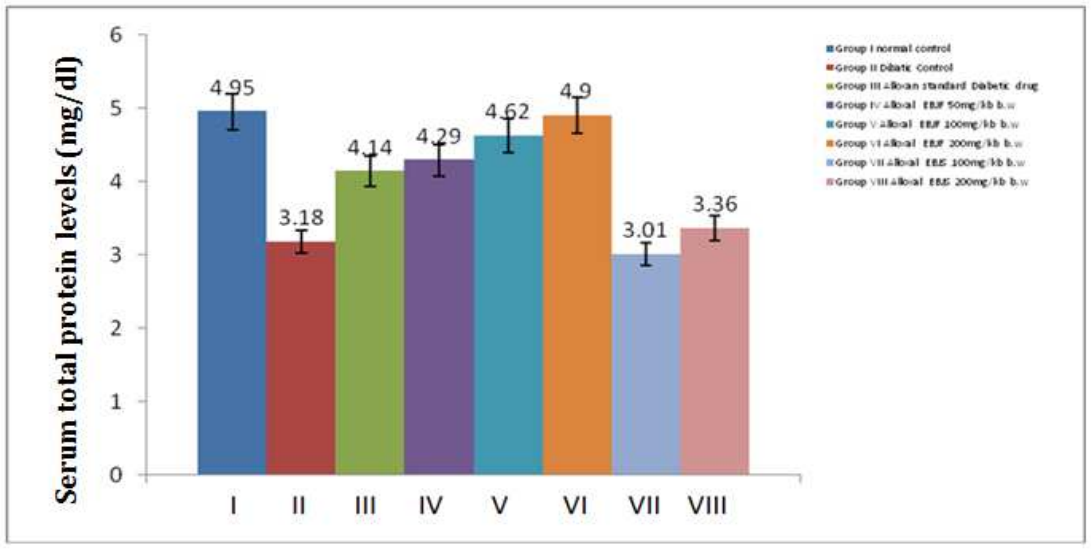

Fig. 4: Effect of Eriobotrya japonica fruits and seeds on serum total protein levels in alloxan-induced diabetic rats

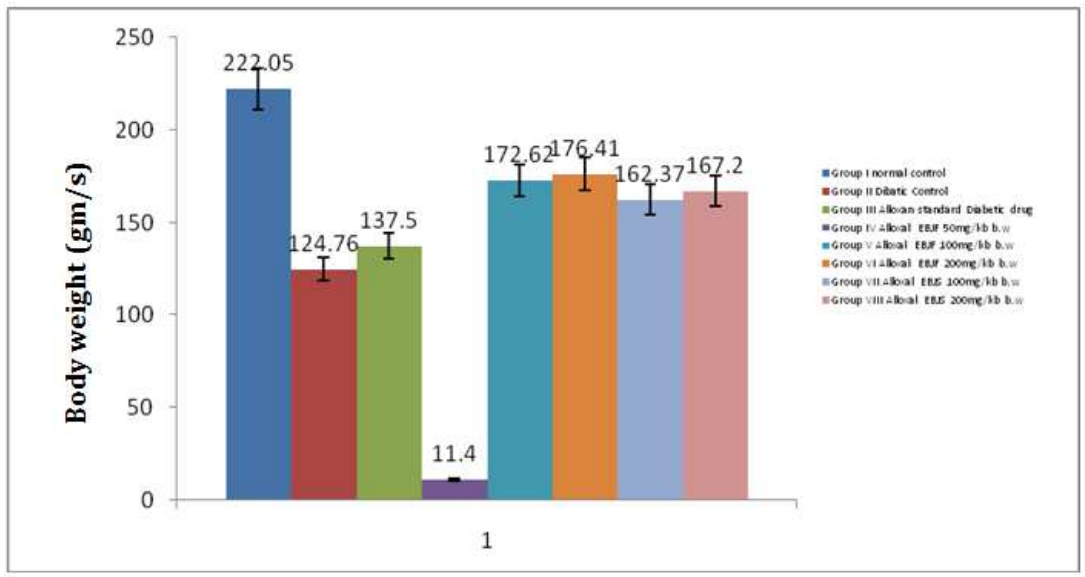

Fig. 5: Effect of Eriobotrya japonica fruits and seeds on body weight ( gms) in alloxan-induced diabetic rats 
The observations are mean \pm SEM of 6 animals as compared to that of Normal Control group (One way ANOVA followed by students " $t$ "test).

Eriobotrya japonica fruits when administered to rats of Group IV, V and VI in $2 \%$ gum acacia showed a non-significant decrease in serum urea and creatinine levels as compared to rats of Group II. The rats in Group II and III also showed a non-significant increase in serum total proteins.

\section{DISCUSSION}

Diabetes is a metabolic disorder where there is resistance in the action of insulin or insufficient insulin secretion or both. Obesity has been one of the risk factors for diabetes mellitus due to which this disease has become one of the most common diseases of the world. It has been observed that young people mostly children have become prone to this disease. Though conventional treatment has been successful in the treatment of this disease but people prefer herbal medicines and other ways like exercising in order to maintain normal glucose levels in their bodies [33-34] For herbal medicines, various screening methods are employed in order to establish the safety and efficacy and also to find the active constituents of the plant.

In India, there are more than 4 crore diabetics and this number will increase around 9 crore by 2030 . India has around 45,000 plant species which have medicinal properties. About 800-1000 plant species have anti-diabetic activity, e. g., Aconitium napeilus, Aloe vera, Carum carvi, Cichorium intybus, Allium cepa, Momordia charantia and many others.

While screening plants for their anti-diabetic and hypoglycaemic activity, laboratory rats and mice are mostly used because they are easily available and economical. First of all, acute toxicity studies were carried out i.e., $\mathrm{LD}_{50}$ and behavioural changes. The optimum dose was $500 \mathrm{mg} / \mathrm{kg}$ b.w. Mice weighing between 20-25 gms were used. They were procured from IIIM Jammu and kept in polypropylene cages under standard conditions of food, water, temperature. Maximum care was taken to ensure that the animals are in good health and free from any infectious disease. Male and female animals were separated from each other so that there was no interference in the evaluation of the biochemical studies. The temperature was kept at $15-25{ }^{\circ} \mathrm{C}$ and humidity of the room was at $70-75 \%$.

The phytochemical investigation of $50 \%$ ethanolic extract of the whole plant of Eriobotrya japonica fruits carried out by standard procedures revealed the presence of alkaloids, flavonoids and glycosides. Biochemical estimations show that there is a nonsignificant decrease in serum urea and creatinine levels and a nonsignificant increase in serum total protein levels.

\section{CONCLUSION}

From the study, it can be concluded that the $50 \%$ ethanolic extract of fruits of Eriobotrya japonica have beneficial effects on serum glucose levels. Further pharmacological and biochemical investigations will clearly elucidate the mechanism of action and will be helpful in projecting this plant as a therapeutic target in diabetic's research.

\section{ACKNOWLEDGEMENT}

We are highly thankful to Sri Krishna Drugs Ltd., C-4 Industrial Area Uppal, Hyderabad for providing a free gift pure sample of Glibenclamide which was used as standard anti-diabetic drug and also to University Grants Commission for financial assistance. The facilities provided by the Department of Pharmaceutical Sciences University of Kashmir for carrying out this work also need appreciation.

\section{AUTHORS CONTRIBUTIONS}

All the author have contributed equally

\section{CONFLICT OF INTERESTS}

We declare that we have no conflict of interest

\section{REFERENCES}

1. Alberti KG, Zimmet PZ. Definition diagnosis and classification of diabetes mellitus and its complications. Part I: diagnosis and classification of diabetes mellitus, provisional report of a WHO consultation. Diabetes Med 1998;15:539-53.

2. King H. Diabetes mellitus: a growing international health care problem. Int Diab Monitor 1997;9:1-6.

3. Grover JK, Yadav S, Vats. Medicinal plants of India with antidiabetic potential. J Ethnopharmacol 2002;81:81-100.

4. Rafiullah MRM, Siddiqui AW, Mir SR, Ali M, Pillai KK, Singh S. Antidiabetic activity of some Indian medicinal plants. Pharm Biol 2006;44:2.

5. Rastogi RP, Mehrotra BN. Compendium of Indian Medicinal Plants. Vol. V. New Delhi, India Publications and Information Directorate (CSIR); 1995. p. 405.

6. Rastogi RP, Mehrotra BN. Compendium of Indian Medicinal Plants. Vol. I. New Delhi, India, Publications and Information's Directorate (CSIR); 1999. p. 326, 398.

7. Rastogi RP, Mehrotra BN. Compendium of India Medicinal Plants. Vol. II. New Delhi Publications and Information Directorate (CSIR); 1990. p. 398.

8. Rastogi RP, Mehrotra BN. Compendium of Indian Medicinal Plants. Vol. II. New Delhi Publications and Information Directorate (CSIR); 1991. p. 660.

9. Chopra RN, Nayar SL, Chopra IC. Glossary of Indian medicinal plants. CSIR Pub, New Delhi; 1966. p. 104.

10. Chopra RN, Chopra IC. A review of work on Indian medical plants, ICMR, New Delhi; 1955.

11. Baljinder S, Seena G, Dharmendra K, Vikas G, Bansal P. Pharmacological potentral of eriobotrya japonica-an overview. Int Res J Pharm 2010;1:95-9.

12. Chen J, Li WL, Wu JL, Ren BR, Zhang HQ. Hypoglycemic effects of a sesquiterpene glycoside isolated from leaves of loquat (Eriobotrya japonica (Thumb,) Lindl. Phytomedicine 2008;15:98-102.

13. El-Hossary GA, Fathy MM, Kassem HA. Phytochemical and biological investigations of Eriobotrya japonica growing in Egypt. Bull Faculty Pharm 2000;38:129-42.

14. Huang Y, Li J, Cao Q, Yu SC, Lv XW, Jin Y, et al. Anti-oxidative effect of triterpene acids of Eriobotrya japonica (Thumb). Lindl. Leaf in chronic bronchitis rats. Life Sci 2006;78:2749-57.

15. Ito H, Kobayashi E, Takamasto Y, Li SH, Hatano T, Sakagami H, et al. Polyphenols from Eriobotrya japonica and their cytotoxicity against human oral tumour cell lines. Chem Pharm Bull (Tokyo) 2000;48:687-93.

16. Yokoto J, Takuma D, Hamada A, Onogawa M, Yoshioka S, Kusenose $\mathrm{M}$, et al. Scavenging of reactive oxygen species by Eriobotrya Japonica seed extract. Biol Pharm Bull 2006;29:467-71.

17. Harborne JB. Phytochemical methods, Chapman and Hall Ltd., London; 1973. p. 49-188.

18. Rafia Rasool, Bashir A Ganai, Seema Akbar, Azra Kamili. Phytochemical screening of Prunella vulgaris L. an important medicinal plant of kashmir pak. J Pharm Sci 2010;23:399-402.

19. Trease GE, Evans WC. Pharmacognosy. 11 $11^{\text {th }}$ edn. Brailliar Tiridel Can. Macmillian Publishers; 1989.

20. Varley H. Practical Clinical Biochemistry New Delhi CBS. Publishers and Distributors V edition; 1980. p. 1, 457.

21. Zender R, Jacot P. A kinetic method for analysis of creatinine using the DSA-50. Anal Lett 1972;5:143-52.

22. Lowry HD, Rosenbroguh NT, Farr AL, Randel RJ. Protein measurement with the folin phenol reagent. J Biol Chem 1951;193:265-75.

23. Trinder P. Determination of glucose in blood using glucose oxidase with an alternative oxygen acceptor. Ann Clin Biochem 1966;6:24-5.

24. Trinder P. Glucose oxidase method. Ann Clin Biochem 1969;6:20-4.

25. Michael JF. Diabetes treatment. Part 1. Diet and Exercise. Clin Diabetes 2007;25:105-9.

26. Pradeep R, Mohan V. The changing scenario of the diabetes epidemic: implications for India. Indian J Med Res 2002;116:121-32. 